Original Research Paper

\title{
Community Structure of Seagrass Field in Litoral Zone of Leweung Sancang Garut Nature Reserve
}

\author{
Dimas Zulfadillah ${ }^{1}$, Diana Hernawati ${ }^{*}$, Diki Muhamad Chaidir ${ }^{1}$ \\ ${ }^{1}$ Jurusan Pendidikan Biologi, Fakultas Keguruan dan Ilmu Pendidikan, Universitas Siliwangi, Jalan \\ Siliwangi No.24, Kecamatan Tawang, Tasikmalaya, Provinsi Jawa Barat, Indonesia.
}

\author{
Article History \\ Received : June $17^{\text {th }}, 2021$ \\ Revised : June $30^{\text {th }}, 2021$ \\ Accepted : July $07^{\text {th }}, 2021$ \\ Published : July $12^{\text {th }}, 2021$ \\ *Corresponding Author: \\ Diana Hernawati, \\ Jurusan Pendidikan Biologi \\ FKIP Universitas Siliwangi, \\ Tasikmalaya, Indonesia. \\ Email: \\ hernawatibiologi@unsil.ac.id
}

\begin{abstract}
Seagrass meadows or seagrass beds are one of the important components in coastal ecosystems. Seagrasses provide ecosystem services for various biota that live in it as well as components of the surrounding coastal ecosystems. The Sancang Nature Reserve is one of the coastal areas that has seagrass communities, and seagrass observation data is needed for reference to conservation strategies. This study aims to determine the condition of the cover and the structure of the seagrass community that fills the littoral zone of the Sancang Nature Reserve using the quadratic transect method, which was conducted from March $17-21,2021$. The data collected were seagrass species, species frequency, species cover and total cover, and the importance value index of species. Observations were made at 3 stations with an area of $100 \mathrm{~m}^{2}$ each along Ciporeang Beach, at each station 30 square transects with a size of $50 \mathrm{~cm}$ were placed, with 1 square transect divided into 25 grids measuring $10 \mathrm{~cm}$. As well as the observation of environmental physical and chemical indicators. The results showed that the seagrass community in the research sites were overgrown by species Cymodocea rotundata and Thalassia hempricii which had a cover condition in the rich category with a percentage of $61.09 \%$. Species densities were $117 \mathrm{i} / \mathrm{m}$ and $679 \mathrm{i} / \mathrm{m}$, species closures were $36.95 \%$ and $25.63 \%$, and the importance value index of species were 1.49 and 0.54 . The difference was significantly influenced by physical indicators such as substrate structure and current velocity, while the chemical indicators at each station did not show a significant difference. Nutrient content data in the substrate at each station is needed to get more detailed conclusions about the factors that affect seagrass cover on the Sancang coast.
\end{abstract}

Keywords: Seagrass Ecosystem, Litoral Zone, Sancang Beach

\section{Pendahuluan}

Lamun merupakan tumbuhan tingkat tinggi (Anthophyta) yang beradaptasi tumbuh terbenam di lingkungan laut, tumbuh membentuk hamparan luas yang di sebut Padang Lamun. Padang Lamun (seagrass bed) adalah hamparan tumbuhan lamun yang menutupi suatu area pesisir/laut dangkal yang dapat terbentuk oleh satu jenis lamun (monospecific) atau lebih (mixed vegetation) (Sjafrie et al. 2018). Tumbuhan ini merupakan salah satu komponen penting penyusun ekosistem pesisir yang memiliki peran tersendidi bagi berbagai organisme laut yang hidup didalamnya. Umumnya Lamun dikenal sebagai penyedia tempat Nusery ground, Feeding ground, dan Spawning ground untuk berbagai biota laut, Zurba (2018) menyebutkan Lamun juga berperan dalam pemerangkap sedimen, pelindung pantai, pemerangkap karbon serta memiliki peluang untuk menjaga kestabilan $\mathrm{pH}$ air laut.

Lamun dapat dipandang sebagai sebuah ekosistem, dalam hal ini terkait dengan interaksi antara flora dan fauna yang bergantung pada komposisi lamun, faktor fisik, dan kimiawi. Lamun juga dapat dipandang sebagai suatu komunitas, dalam hal ini lamun merupakan komunitas dan penyusun komunitas itu sendiri, Rahmawati et al., (2014) menjelaskan satu jenis lamun atau beberapa jenis lamun umumnya membentuk hamparan luas disebut Komunitas Padang Lamun. Berdasarkan morfologi karakteristik pertumbuhan komunitas lamun dapat dibagi enam kategori yaitu (Azkab, 2000) :

a. Parvozosterids, dengan daun memanjang dan sempit: Halodule, Zostera sub-marga Zosterella. 
b. Magnozosterids, dengan daun memanjang dan agak lebar: Zostera sub-marga Zostera, Cymodocea dan Thalassia.

c. Syringodiids, dengan daun bulat seperti lidi dengan ujung runcing: Syringodium.

d. Enhalids, dengan daun panjang dan kaku seperti kulit atau berbentuk ikat pinggang yang kasar Enhalus, Posidoniq, Phyllospadix.

e. Halophilids; dengan daun bulat telur, dips, berbentuk tombak atau panjang, rapuh dan tanpa saluran udara: Halophila

f. Amphibolids, daun tumbuh teratur pada kiri dan kanan: Amphibolis, Thalassodendron, dan Heterozostera.

Azkab (2000) menjelaskan komunitas parvozosterid dan halophilid umumnya sangat sederhana, komunitas ini biasanya terbentuk dari 1 atau 2 jenis lamun. Pada komunitas ini hampir tidak ditemui tumbuhan lain dan sedikit fauna efifitik. Kemudian komunitas magnozosterid dan syringodiid memperlihatkan banyak perbedaan, komunitas tersebut kadang-kadang hanya terdiri 1 jenis lamun, tetapi pada kasus lain dapat terdiri dari beberapa jenis lamun. Pada komunitas ini fauna efipitik, dan flora efipitik berkembang

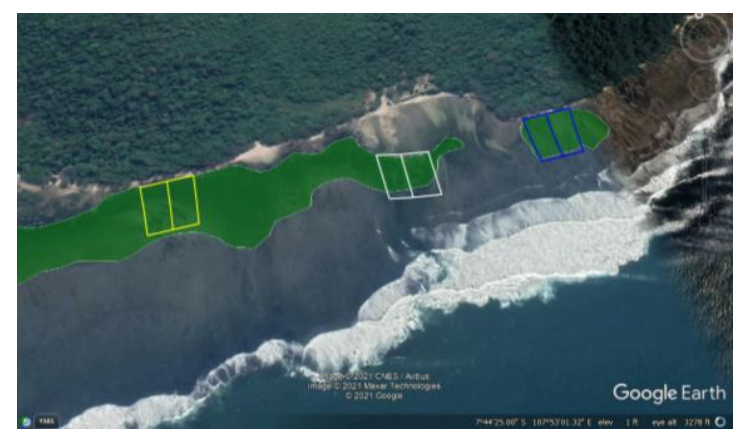

Gambar 1. Stasiun Pengamatan

\section{Bahan dan Metode}

\section{Waktu dan Tempat}

Penelitian ini dilaksanakan pada tanggal 17 - 21 Maret 2021, dengan lokasi sampel di sepanjang Pantai Ciporeang. Data yang.dikumpulkan berupa jenis lamun, kerapatan, frekuensi jenis, penutupan jenis dan penutupan total, serta nilai indeks penting jenis. Pengamatan dilakukan pada 3 stasiun dengan masing-masing luas $100 \mathrm{~m}^{2}$ disepanjang Pantai Ciporeang, pada setiap stasiun ditempatkan 30 transek kuadrat dengan ukuran $50 \mathrm{~cm}$ yang dengan baik, magnozosterid tropis dan subtropis sering berassosiasi dengan algae hijau (Cauluerpa sp., Halimeda sp., Penicillus sp.,), di mana mereka menjalar atau membentuk struktur seperti akar. Kemudian komunitas jenis enhalid dan amphibolid memperlihatkan adanya perbedaan, walaupun mereka secara normal terdiri hanya satu jenis tumbuhan berbunga (angiospermae). Pada komunitas ini asosiasi fauna dan flora efipitik dapat terlihat dengan baik seprti pada magnozosterid, vegetasi komunitas ini cukup padat dan terdapat algae rhizofitik.

Leenhardt et al., 2015 (dalam Syukur, 2015) menjelaskan untu memahami lebih dalam mengenai peran dan fungsi lamun dalam ekosistem pesisir perlu dilakukan penelitian mengenai sosial-ekologi, manajenmen pengelolaan lamun, dan model keberlanjutan berbasis data dari tempat padang lamun. Cagar Alam Leweung Sancang memiliki kawasan perlindungan laut seluas 1.150 ha yang menyimpan tutupan lamun yang luas, pembaharuan informasi mengenai kondisi dan struktur komunitas seperti hal-nya tujuan penelitian ini diharap dapat memberikan kontribusi dalam upaya konservasi.

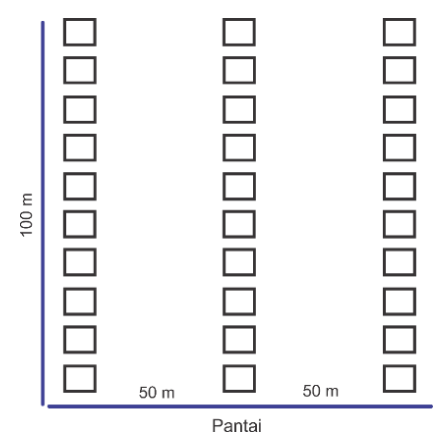

Gambar 2. Model Sampling

diletakan tegak lurus garis pantai, 1 buah stransek kuadrat dibagi menjadi 25 kisi berukuran $10 \mathrm{~cm}$. dengan jarak antar transek kuadrat $10 \mathrm{~m}$. Titik awal transek diletakan adalah pada jarak $5-10$ meter dari tepi lamun dekat garis pantai.

Pada setiap transek kuadrat di identifikasi setiap jenis lamun yang ditemukan, dan dihitung jumlah tegakan dari setiap spesies yang ditemukan, dan secara visual diamati berapa persen luas yang ditutupi Lamun dalam setiap transek kuadrat. Selanjutnya indikator fisik dan kimia diukur menggunakan alat dan metode yang relevan. 


\section{Hasil dan Pembahasan}

\section{Karakteristik Pesisir Sancang}

Berdasarkan hasil pengamatan, Pantai Ciporeang merupakan perairan dangkal yang jernih dan tenang, $\pm 200 \mathrm{~m}$ dari bibir pantai ke arah laut merupakan rataan karang dengan substrat campuran pasir dan lumpur. Ujung rataan karang memecah ombak, sehingga gelombang yang masuk pada saat pasang total normal cukup kecil, dengan kecepatan arus berkisar $0,17 \mathrm{~m} / \mathrm{s}-0,24 \mathrm{~m} / \mathrm{s}$. Kedalaman pada saat pasang total normal berkisar antara $1-2 \mathrm{~m}$, dan pada saat surut kedalamannya kurang dari 1 $\mathrm{m}$, dalam keadaan pasang abnormal atau saat cuaca buruk dan gelombang tinggi, kecepatan arus dapat lebih dari $0,50 \mathrm{~m} / \mathrm{s}$ dan kedalaman terutama di stasiun 2 dapat lebih dari $3 \mathrm{~m}$. Hal tersebut dapat menyebakan Lamun dan beberapa jenis Alga terlepas dari substratnya.

Suhu di wilayah sampel berkisar antara $28-35^{\circ} \mathrm{C}$, pada pagi sampai siang hari suhu perairan berada di angka paling rendah, kemudian menuju sore hari suhu perairan menjadi lebih hangat, lalu pada malam hari suhu kembali turun. Salinitas dan derajat keasaman relativ sama di setiap stasiun, salinitas berkisar di angka $3,2 \%$ dan derajat keasaman berada di angka 7 atau netral. Berdasarkan data yang di peroleh dan Keputusan Menteri Negara Lingkungan Hidup No.51 Tahun 2004 Tentang Baku Mutu Air Laut, kondisi perairan Pantai Ciporeang tergolong baik, dan memenuhi sarat hidup tumbuhan Lamun.

Tabel 1. Rata-rata data klimatik sebagai faktor abiotic lingkungan

\begin{tabular}{ccccccc}
\hline \multicolumn{7}{c}{ Data Klimatik } \\
\hline Stasiun & $\begin{array}{c}\text { Kecepatan } \\
\text { Arus }\end{array}$ & $\begin{array}{c}\text { Intensitas } \\
\text { Cahaya }\end{array}$ & $\begin{array}{c}\text { Kedalaman } \\
\text { Pasang }- \text { Surut }\end{array}$ & Suhu & Salinitas & Ph \\
\hline Stasiun 1 & $0.17 \mathrm{~m} / \mathrm{s}$ & $100 \%$ & $<1 \mathrm{~m}$ & $29-35^{\circ} \mathrm{C}$ & $3.2 \%$ & 7 \\
\hline Stasiun 2 & $0.24 \mathrm{~m} / \mathrm{s}$ & $100 \%$ & $>1 \mathrm{~m}$ & $28-32^{\circ} \mathrm{C}$ & $3.2 \%$ & 7 \\
\hline Stasiun 3 & $0.20 \mathrm{~m} / \mathrm{s}$ & $100 \%$ & $<1 \mathrm{~m}$ & $28-32^{\circ} \mathrm{C}$ & $3.2 \%$ & 7 \\
\hline
\end{tabular}

\section{Temuan Spesies Lamun}

\section{a. Cymodocea rotundata}

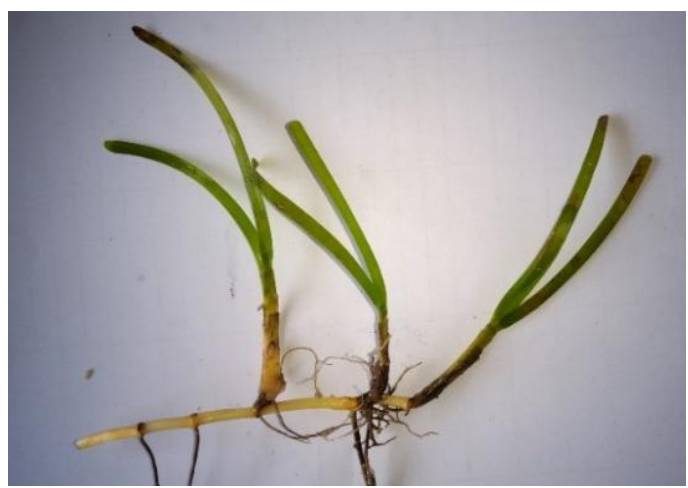

Gambar 3. Morfologi Cymodocea rotundata

(Rawung et al., 2018) menjelaskan spesies Cymodocea rotundata memiliki umum daun panjang dan lurus, memiliki satu tulang daun di tengah yang tidak terlalu menonjol, seludang daun menutup sempurna dan ujung daun membentuk m. Syukur, (2015) lebih rinci menjelaskan spesies ini memiliki $3-4$ daun dengan panjang $4-15 \mathrm{~cm}$ dan lebar $2-4 \mathrm{~mm}$.
Kemudian Sjafrie et al., (2018) menjelaskan ciri yang membedakanya dengan Cymodocea serulata yaitu seludang daun menutup sempurna.

b. Thlassia hempricii

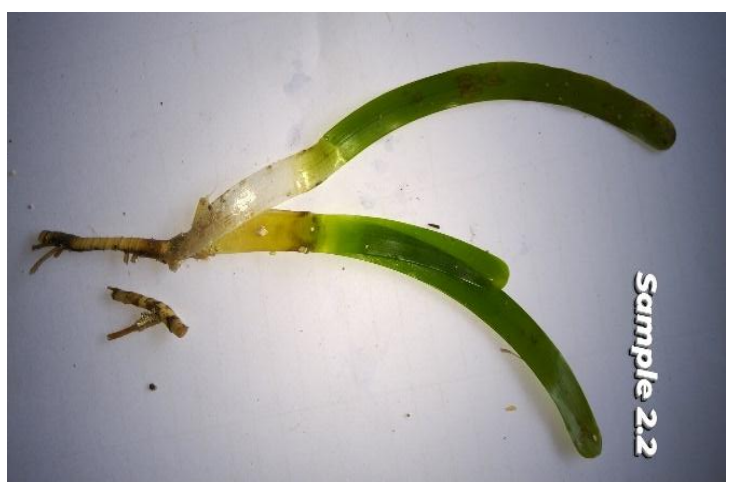

Gambar 4. Morfologi Thalassia hempricii

Thalassia memiliki ciri khusus bercak coklat pada daun, rhizome beruas dan tebal, dan daun mirip Cymodocea rotundata (Sjarfrie et al. 2018). Rhizoma tebal sampai $5 \mathrm{~mm}$, pada umumnya panjang daun mencapai $40 \mathrm{~cm}$ dan lebar $0,4-1,0 \mathrm{~cm}$, helai daun berbentuk pita (Syukur, 2015). 
Lamun di perairan Pantai Ciporeang termasuk kedalam tipe pertumbuhan Magnozosterid, terdiri dari spesies Thalassia hempricii dan Cymodocea rotundata. Azkab (2000) menjelaskan tipe pertumbuhan Magnozosterid dapat dijumpai di berbagai substrat namun terbatas pada zona litoral sampai sublittoral, dengan batas kedalaman jenisnya antara $10-12 \mathrm{~m}$. Cymodocea rotundata mendominasi substrat pasir pada perairan dangkal dan memiliki toleransi tinggi pada daerah perairan terbuka (tidak terendam air), sedangkan Thalassia hempricii hidup bersama Cymodoce rotundata namun mendominasi substrat lumpur pada daerah yang selalu tergenang air.

Berdasarkan hasil pengamatan, serta mengacu pada Keputusan Menteri Negara Lingkungan Hidup No.200 tahun 2004 penutupan Lamun di Pantai Ciporeang tergolong Kaya/Sehat karena berada pada kisaran rata-rata penutupan $60 \%$.

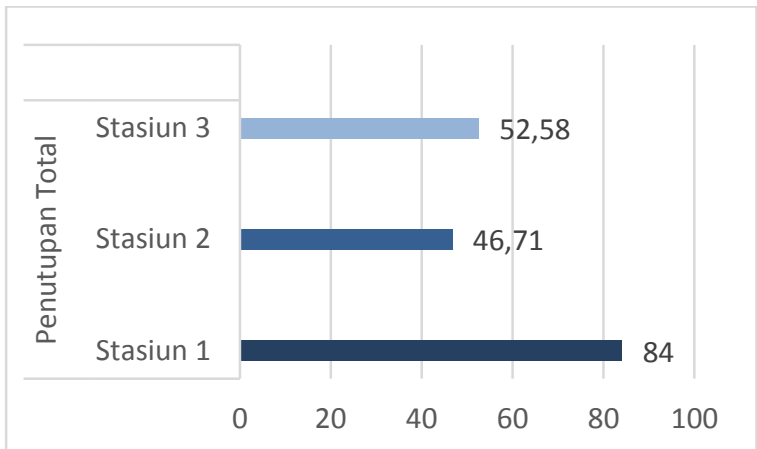

Gambar 5. Presentase penutupan

\section{Komposisi Padang Lamun Berdasarkan Kerapatan Jenis.}

Kerapatan jenis merupakan perbandingan jumlah individu yang muncul dalam suatu satuan luas area. Kerapatan merepresentasikan kondisi lingkungan habitat Lamun, semakin baik kondisi lingkungan maka semakin baik juga kemampuannya menunjang pertumbuhan Lamun. Zurba (2018) perbedaan kerapatan jenis menggambarkan pola sebaran jenis yang dipengaruhi oleh karakteristik kondisi lingkungan.

Berdasarkan hasil pengamatan, nilai kerapatan tertinggi didapat pada stasiun 1 dimana Cymodocea rotundata dan Thalassia Hempricii masing-masing mencapai \pm 836 individu $/ \mathrm{m}^{2}$ dan \pm 242 individu $/ \mathrm{m}^{2}$. Kemudian stasiun 2 Cymodocea rotundata dan Thalassia Hempricii masing masing mencapai $\pm 589 \mathrm{individu} / \mathrm{m}^{2}$ dan \pm 77 individu/ $\mathrm{m}^{2}$, dan stasiun 3 , masing-masing berada pada kisaran \pm 614 individu $/ \mathrm{m}^{2}$ dan \pm 36 individu $/ \mathrm{m}^{2}$.

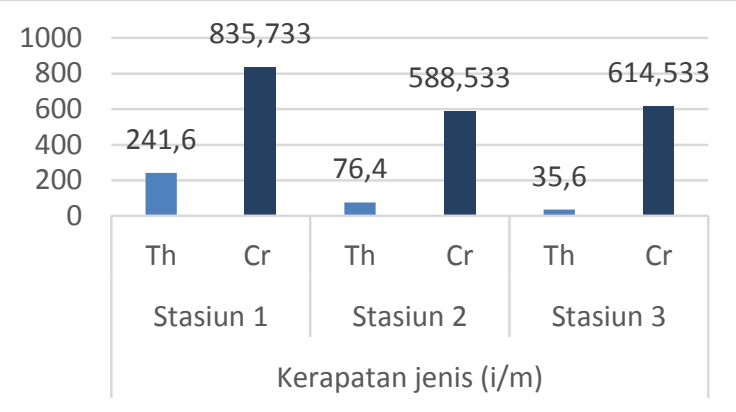

Gambar 6. Perbandingan Kerapatan Jenis

Nilai kerapatan jenis tertinggi disetiap stasiun dominasi oleh Cymodocea rotundata. Hal ini disebabkan sebagian besar substrat di stasiun 1, stasiun 2, dan stasiun 3 adalah pasir dan sebagian besar habitat lamun tidak tergenang air pada saat surut, hal tersebut menguntungkan jenis Cymodocea rotundata karena dapat tumbuh baik pada substrat pasisr serta memiliki toleransi tinggi terhadap perairan terbuka (tidak tergenang air). Sedangkan Thalassia hempricii tidak diuntungkan dengan kondisi lingkungan, Thalassia hemprichii merupakan jenis lamun tropis yang paling sensitif terhadap tekanan lingkungan (Tussenbroek; Zulfikar et al., 2020)

\section{Komposisi Padang Lamun Berdasarkan Frekuensi Jenis.}

Frekuensi erat kaitannya dengan tingkat penyebaran suatu spesies dalam lokasi sampling, semakin tinggi frekuensi suatu spesies maka sebarannya semakin luas dan menyebar (Utami, I., dan Putra I., L., 2020). Dalam penelinitan ini hanya ditemukan 2 spesies Lamun dalam satu komunitas heterogen, yaitu Cymodocea rotundata dan Thalassia hempricii. Di semua stasiun Cymodocea rotundata memiliki nilai frekuensi jenis lebih besar dari Thalassia hempricii.

Perbedaan persebaran kedua jenis tersebut secara signifikan dipengaruhi oleh tipe substrat dan karakteristik habitat. Thalassia hempricii lebih sering di temukan di stasiun 1 , karena terdapat substrat berupa campuran pasir dan lumpur. Spesies ini biasa ditemukan mendominasi pada substrat berlumpur (Zurba, 2018). Sedangkan Cymodocea rotundata, didapati mendominasi sebagian besar wilayah 
karena dapat beradaptasi dengan baik pada substrat pasir dan perairan terbuka.

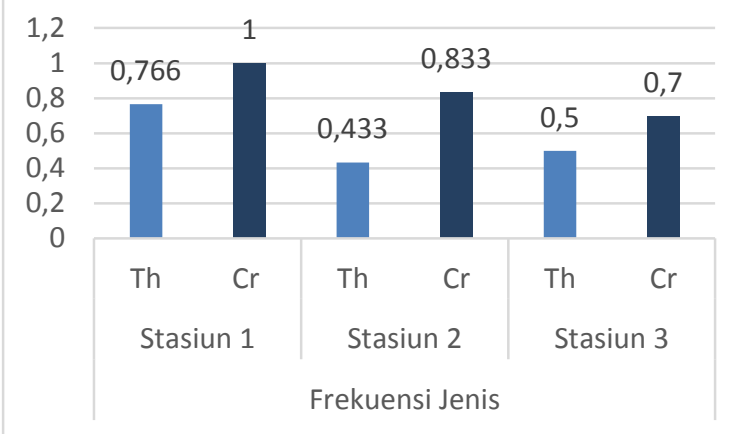

Gambar 7. Perbandingan Frekuensi Jenis

\section{Frekuensi Padang Lamun Berdasarkan Penutupan Jensi.}

Penutupan jenis menggambarkan perkiraan tutupan suatu jenis lamun dalam suatu komunitas dengan satuan luas area tertentu. Nilai penutupan jenis dipengruhi oleh frekuensi jenis serta morfologi masing-masing spesies, spesies dengan morfologi besar akan memiliki nilai penutupan yang cenderung lebih besar dari spesies dengan ukuran morfologi kecil dan semakin besar nilai frekuensi jenis semakin besar juga nilai penutupan jenisnya. Hartati et al. (2012) nilai estimasi penutupan juga dipengaruhi oleh kondisi pasang surut dan kerapatan lamun.

Nilai penutupan tertinggi disetiap stasiun di dominasi oleh spesies Cymodocea rotundata karena tumbuh sebagian besar area. Sedangkan, jenis Thalassia hempricii walaupun dengan kerapatan dan frekuensi yang jauh lebih kecil dari Cymodocea rotundata namun dapat mencapai setengah dari nilai tutupan Cymodocea rotundata karena memiliki ukuran morfologi yang lebih besar.

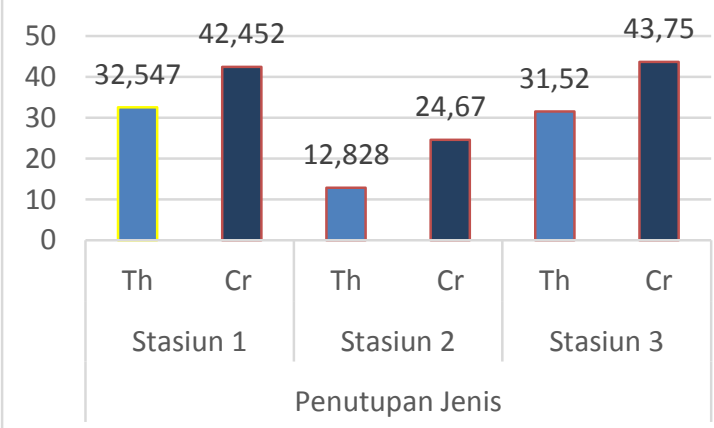

Gambar 8. Perbandingan Penutupan Jenis

Indeks Nilai Penting Lamun
Nilai indeks penting merupakan perhitungan secara keseluruhan yang digunakan untuk menduga peran suatu spesies dalam sebuah komunitas. Nilai indeks penting dipengaruhi langsung oleh penutupan, kerapatan, dan frekuensi. Nabila Zurba (2018) menjelaskan indeks nilai penting memberikan gambaran mengenai pengaruh atau peranan suatu jenis tumbuhan terhadap suatu daerah.

Bedasarkan hasil pengamatan diperoleh NIP pada setiap stasiun didominasi oleh Cymodocea rotundata, ini menunjukan spesies ini berpengaruh besar terhadap jenis lamun lainnya di stasiun pengamatan. Jenis ini memiliki toleransi yang baik terhadap perubahan lingkungan yang cukup signifikan, sehingga dapat tumbuh dan mendominasi di ketiga stasiun pengamatan. Jenis yang dominan memiliki produktivitas yang lebih besar dari jenis lainnya, oleh karena itu Cymodocea rotundata memiliki peran yang besar dalam komunitas lamun dan ekosistem pesisir.

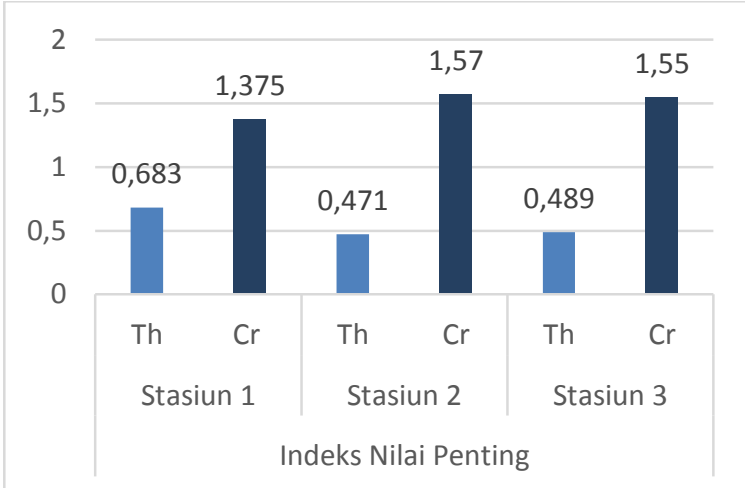

Gambar 9. Perbandingan Indeks Nilai Penting Jenis

\section{Faktor-faktor yang Mempengaruhi Pertumbuhan Lamun.}

Zurba (2018) walaupun memiliki kemampuan beradaptasi tumbuh di berbagai substrat dan memiliki tingkat toleransi yang cukup tinggi terhadap perubahan lingkungan, Lamun tetap memiliki batas minimal syarat hidup. Faktor utama yang menjadi pembatas pertumbuhan lamun di Pantai Ciporeang adalah tipe substrat, kecepatan arus, dan pasang surut. Sedangkangkan faktor kimia tidak menunjukan perbedaan yang signifikan di setiap stasiun pengamatan.

Hartati et al., (2012) Lamun umunya tumbuh di daerah pasang surut dan perairan pantai atau goba dengan substrat berupa lumpur, 
pasir, dan pecahan karang. Saputro et al., (2018) tipe substrat pasir kasar dan pasir halus berpengaruh kecil terhadap kerapatan lamun, artinya ada faktor lain yang mempengaruhi perbedaan karapatan pada setiap substrat. Hartati et al., (2017) Lumpur dalam substrat mengandung bahan organic hasil pelapukan atau dekomposisi yang mengandung banyak nutrient. Substrat di Pantai Ciporeang didominasi oleh pasir dan karang mati. Dewi, Nurul \& Prabowo, Sigit, (2015) komposisi substrat karbonat yang berasal dari pecahan karang dapat menyebabkan kurangnya ketersediaan fosfat bebas, namun kondisi ini masih dapat diatasi oleh kemampuan lamun yang dapat mengambil zat hara (ammonia dan fosfat) dari kolom air menggunakan daun, walaupun konsentrasi zat hara dalam kolom air tersebut rendah. Handayani et al., (2016) menjelaskan faktor lingkungan yang mempengaruhi kuantitas penutupan, menurutnya terdapat hubungan nyata antara kandungan nutrien dalam substrat (nitrat dan fosfat) terhadap kepadatan lamun dengan koefisien korelasi $0,832 *$ dan $-0,703$.

Faktor berikutnya adalah kecepatan arus, Lamun cenderung tumbuh di perairan yang tenang dan tidak keruh. Arus pasang surut yang kuat menyebabkan lamun sulit menancapkan akarnya pada dasar perairan sehingga kurang berkembang-biak dengan baik (Dewi, Nurul \& Prabowo, Sigit, 2015). Selain itu arus berperan dalam membawa bahan organik, sedimen, dan oskigen terlarut, Sarinawaty et al. (2020) arus yang tenang memudahkan akar untuk mengikat sedimen. Kecepatan arus di Pantai Ciporeang berkisar dari 0,17-0,24 m/s, kecepan arus yang tidak begitu kuat membuat banyak biota yang berasososiasi dengan daun dan rizome Lamun sehingga lamun dapat berkembang biak dengan baik.

Faktor lainnya adalah pasang surut, Christon et al. (2012) menjelaskan pola pasang surut akan mempengaruhi larutnya nutrien yang bermanfaat bagi pertumbuhan lamun. Pada lokasi penelitian ketinggian permukaan air saat pasang tidak lebih dari $2 \mathrm{~m}$, dan pada saat surut sebagian besar habitat Lamun di Pantai Ciporeang menjadi perairan terbuka (tidak tergenang air). Hal ini mempengaruhi distribusi spesies Thalassia hempricii, spesies ini kurang dapat beradaptasi di perairan terbuka sehingga hanya menutupi sebagian wilayah saja, berbeda dengan spesies Cymodocea rotundata yang memiliki toleransi tinggi terhadap perairan terbuka sehingga dapat menutupi sebagian besar wilaya perairan.

\section{Peran Ekologis Lamun}

Padang Lamun menyediakan jasa ekosistem. Jasa ekosistem merupakan sesuatu dari ekosistem yang dapat bermanfaat bagi manuisa, Millenium Ecological Assessment (dalam Zurba, 2018) membagi jasa ekosistem menjadi regulating (pengaturan), supporting (pendukung), provisioning (penyedia) dan cultural services (budaya). Dalam hal ini yang termasuk kedalam peran ekologis adalah regulating (pengaturan), supporting (pendukung), dan provisioning (penyedia).

\section{a. Pengaturan (Regulating)}

Zurba, (2018) sebagai regulating services lamun berperan sebagai pelindung pantai, mengendapkan sedimen, menyerap karbon dan menyediakan oksigen. Dalam kaitannya sebagai pelindung pantai Koch et al. dalam Cappenberg, Hendrik \& Wulandari, Diah (2019) menjelaskan, dengan sistem rizhoma yang menyilang dan pertumbuhan yang membentuk padang lamun, tumbuhan ini mampu mesntabilkan dasar laut dan mencegah abrasi yang disebabkan oleh gelombang dan arus laut yang besar. Secara fisik lamun juga mencegah sedimen dari daratan masuk ke komunitas terumbu karang, dimana jika sedimen tersebut masuk kedalam komunitas terumbu karang, maka akan menutup permukaan hewan karang dan menghambat fotosistesis zooxanthellae yang hidup didalamnya

Sebagai pemerangkap karbon, Lamun mengikat karbon dioksida yang terlarut dalam air sebagai bahan baku untuk fotosintesis. Padang lamun sangat efektif menyerap $\mathrm{CO}_{2}$ dengan serapan sebesar 1.867 ton $/ \mathrm{km}^{2}$ (48\%) relatif lebih tinggi dibandingkan mangrove sebesar 806 ton $/ \mathrm{km}^{2}$ (21\%) dan karang sebesar 1.197 ton $/ \mathrm{km}^{2}$ (31\%) (Simamora, dalam Supriyadi, I.H et al. 2018). Kemudian hasil penelitian Sjafrie et al. (2018) diketahui bahwa padang lamun dapat menyerap ratarata 6,59 ton $\mathrm{C} / \mathrm{ha} /$ tahun atau setara dengan 24,13 ton $\mathrm{CO}_{2} / \mathrm{ha} /$ tahun (Prayudha et al., 2018).

b. Pendukung (Suporting)

Latuconsina (2011) menjelaskan, dengan produktivitas yang tinggi lamun menyediakan tempat pembesaran (nursery ground), mencari makan (feeding ground), dan memijah (spawning ground), selain itu massa dan daun lamun yang lebat mampu 
menurunkan pencahayaan apada siang hari, melindungi dasar perairan dari isolasi sehingga memungkinkan perkembangan lingkungan mikro pada dasar vegetasi.

Lamun juga memiliki konektivitas dengan ekosistem mangrove dan terumbu karang. Azkab (2014) menjelaskan sekitar $45 \%$ dari produksi total dibawa ke situs lain di sekitarnya, dan serasah lamun dapat membantu kelimpahan zooplankton. Daun lamun dan serasah lamun digunakan oleh avertebrata yang selanjutnya avertebrata tersebut menjadi sumber makanan bagi ikanikan muda (juvenile) atau karnivora lain.

c. Penyedia (Provisioning)

Sebagai provisioning services, ekoosistem lamun berperan sebagai sumber ikan, invertebrata, benih, pupuk, bioprospecting, tempat meletakkan perangkap dan tempat budidaya (Zurba, 2018). Dalam hal ini Padang Lamun berperan Hotspot berbagai biota Laut yang bermanfaat bagi manusia, berdasarakan hasil observasi masyarakan pesisir Ciporeang sering mencari ikan pada waktu surut di malam hari atau istilahnya ngobor, dimana lokasi pencariannya tersebut berada di stasiun 1 dimana kerapatan dan tutupan Lamun lebih tinggi dari 2 stasiun lainnya.

Sebagai penyedia jasa ekosistem, tentunya peneliti mendapati bebagai biota seperti Moluska, Echinodermata, dan porifera yang hidup berasosiasi dalam komunitas Lamun. Hal ini dapat menjadi dasar untuk penelitian lebih lanjut tentang studi asosiasi Lamun dengan biota yang hidup didalamnya.

\section{Kesimpulan}

Bedasarkan hasil penelitian, ditemukan 2 spesies Lamun dari 2 falimi yang berbeda yaitu Cymodocea rotundata dan Thalassia hempricii, dengan nilai tutupan total $61,09 \%$ yang artinya kondisi tutupan Lamun pada lokasi penelitian termasuk kedalam kategori baik atau kaya. Presnentase tututupan jenis masing-masing berkisar di 36,95\% dan 25,63\%, serta frekuensi jenis masing-masing berkisar di 0,84 dan 0,56. Perbedaan presentse tutupan jenis dan frekuensi jenis secara signifikan dipengearuhi oleh morfologi Lamun, kemampuan adaptasi Lamun, dan komposisi substrat. Thalassia hempricii memiliki morfologi yang lebih besar sehingga nilai tutupannya akan cenderung lebih besar, namun karena kemampuan adaptasi Thalassia hempricii terhadap perairan terbuka tidak lebih baik dari Cymodocea rotundata, mengakibatkan spesies tersebut hanya tumbuh dan menutupi sebagian kecil wilayah yang selalu tergenang air dan memiliki substrat campuran pasir dan lumpur. Sedangkan Cymodocea rotundata yang memiliki kemampuan adaptasi pada substrat pasir dan perairan terbuka, dapat tumbuh dan menutupi sebagian besar wilayah.

\section{Ucapan terima kasih}

Penulis mengucapkan terimakasih kepada Kelompok Studi Biodiversitas dan Konservasi Universitas Siliwangi, terutama Rifqi K, Dedi K, M Nizar, dan Fahmi M yang telah ikut membantu proses pengambilan data penelitian, serta warga Desa Sancang yang telah menerima dengan sangat baik kedatangan tim peneliti. Dana penelitian bersumber dari dana pribadi.

\section{Referensi}

A.W, H., \& Wulandari, D. (2019). Struktur Komunitas Moluska Di Padang Lamun Perairan Pulau Belitung Provinsi Bangka Belitung Community. Jurnal Ilmu Dan Teknologi Kelautan Tropis, 11(9), 1689$1699 . \quad$ https://doi.org/: http://doi.org/10.29244/jitkt.v11i3.26133

Azkab, M. H. (2000). Struktur dan Fungsi pada Komunitas Lamun. Jurnal Oseana, 25(3), 9-17.

Azkab, M. H. (2014). Peran Padang Lamun Untuk Kehidupan Hewan Asosiasi. Oseana, XXXIX(2), 49-54.

Christon, Djunaedi, O., \& Purba, N. (2012). Pengaruh Tinggi Pasang Surut Terhadap Pertumbuhan Dan Biomassa Daun Lamun Enhalus Acoroides Di Pulau Pari Kepulauan Seribu Jakarta. Jurnal Perikanan Dan Kelautan, 3(3), 287-294. https://www.neliti.com/publications/1248 21/pengaruh-tinggi-pasang-surutterhadap-pertumbuhan-dan-biomassadaun-lamun-enhalu

Handayani, D., Armid, A., \& Emiyarti, E. (2016). Hubungan Kandungan Nutrien Dalam 
Substrat Terhadap Kepadatan Lamun Di Perairan Desa Lalowaru Kecamatan Moramo Utara. Jurnal Sapa Laut, 1(2), $42-53$.

Hartati, R., Djunaedi, A., Hariyadi, \& Mujiyanto. (2012). Struktur Komunitas Padang Lamun Di Perairan Pulau Kumbang, Kepulauan Karmunjawa. Ilmu Kelautan, 17(4), 217-225.

Hartati, R., Widianingsih, W., Santoso, A., Santoso, A., Endrawati, H., Zainuri, M., Riniatsih, I., Saputra, W. L., \& Mahendrajaya, R. T. (2017). Variasi Komposisi Dan Kerapatan Jenis Lamun Di Perairan Ujung Piring, Kabupaten Jepara. Jurnal Kelautan Tropis, 20(2), 96. https://doi.org/10.14710/jkt.v20i2.1702

Kusuma Dewi, N., \& Ari Prabowo, S. (2015). Status Padang Lamun Pantai-Pantai Wisata di Pacitan. Biogenesis: Jurnal Ilmiah Biologi, 3(1), 53-59. https://doi.org/10.24252/bio.v3i1.567

Latuconsina, H. (2011). Komposisi jenis dan struktur komunitas ikan padang lamun di perairan Pantai Lateri Teluk Ambon Dalam. Agrikan: Jurnal Agribisnis Perikanan, 4(1), 30. https://doi.org/10.29239/j.agrikan.4.1.3036

Prayudha, N. D. M. S. U. E. H. B., Rahmat, I. H. S. M. Y. I., \& Suyarso, K. A. S. R. (2018). Status Padang Lamun. In Pusat Penelitian Oseanografi-LIPI (Vol. 2, Issue 9). Puslit Oseanografi - LIPI.

Rahmawati, S., Irawan, A., Supriyadi, I. H., \& Azkab, M. H. (2014). Panduan Monitoring Padang Lamun (M. Hutomo \& A. Nontji (eds.); 1st ed., Issue 1). PT. Sarana Komunikasi Utama.

Rawung, S., Tilaar, F. F., Rondonuwu, A. B., Email, P., Inventarisasi, K., \& Station, M. F. (2018). Jurnal Ilmiah Platax Inventarisasi Lamun Di Perairan Marine Field Station Likupang Timur Kabupaten Minahasa Utara ( The Inventory of Seagrasses in Marine Field Station of Faculty of Fisheries and Marine Science in Subdistrict of East Likupang District Nor. Ilmiah Platax, 6(2), 38-45.
Republik Indonesia. (2004). Keputusan Menteri Negara Lingkungan Hidup Nomor 200 Tahun 2004 Tentang Kriteria Baku Kerusakan dan Pedoman Penentuan Status Padang Lamun. Lembar Negara RI Tahun 2004, No.200. JakartaRepublik Indonesia. (2004). Keputusan Menteri Negara Lingkungan Hidup No 51 Tahun 2004 tentang Baku Mutu Air Laut. Lembaran Negara Republik Indonesia Tahun 2004, No. 51. Jakarta.

Saputro, M. A., Ario, R., \& Riniatsih, I. (2018). Sebaran Jenis Lamun di Perairan Pulau Lirang Maluku Barat Daya Provinsi Maluku. Marine Research, 7(2), 97-105. https://doi.org/: https://doi.org/10.14710/jmr.v7i2.25898

Sarinawaty, P., Idris, F., \& Nugraha, A. H. (2020). Karakteristik Morfometrik Lamun Enhalus acoroides dan Thalassia hemprichii di Pesisir Pulau Bintan. Journal of Marine Research, 9(4), 474484.

https://doi.org/https://doi.org/10.14710/jm r.v9i4.28432

Supriyadi, I.H, ., Iswari, M.Y, ., \& Suyarso, et al. (2018). Kajian Awal Kondisi Padang LAmun Di Perairan Timur Indonesia. Jurnal Segara, 14(3), 169-177. http://ejournal-

balitbang.kkp.go.id/index.php/segara

Syukur, A. (2015). Distribusi, Keragaman Jenis Lamun (Seagrass) dan Status Konservasinya di Pulau Lombok. Jurnal Biologi Tropis, 15(2), 171-182.

Utami, I., dan Putra I., L., I. (2020). Ekologi Kuantitatif Metode Sampling dan Analisis Data Lapangan (Issue October 2020).

Zulfikar, A., Boer, M., Adrianto, L., \& Puspasari, R. (2020). Kajian Hubungan Allometrik dan Biomassa Lamun Thalassia hemprichii sebagai Bioindikator Lingkungan. Jurnal Ilmu Pertanian Indonesia, 25(3), 356-364. https://doi.org/10.18343/jipi.25.3.356

Zurba, N. (2018). Pengenalan Padang Lamun, Suatu Ekosistem yang Terlupakan. Unimal, 53(9), 1-114. 
Zulfadillah, et al. (2021). Jurnal Biologi Tropis, 21 (2): 526 - 533

DOI: http://dx.doi.org/10.29303/jbt.v21i2.2725 